\title{
Familial atrial fibrillation
}

\author{
INSERM
}

\section{Source}

INSERM. (1999). Orphanet: an online rare disease and orphan drug data base. Familial atrial fibrillation. ORPHA:334

Familial atrial fibrillation is a rare, genetically heterogenous cardiac disease characterized by erratic activation of the atria with an irregular ventricular response, in various members of a single family. It may be asymptomatic or associated with palpitations, dyspnea and light-headedness. Concomitant rhythm disorders and cardiomyopathies are frequently reported. 